\title{
Identity Crisis and the Challenge of Peace-Building in Wukari-Nigeria
}

\author{
Kingsley Nnorom \\ Department of Sociology, Kwararafa University Wukari, Wukari-Nigeria \\ Jude Odigbo
}

Department of Political Science, University of Nigeria, Nsukka

\section{Doi:10.5901/ajis.2015.v4n1p17}

\begin{abstract}
In the past few years, the intensity of crisis in Wukari has astonishingly created one of the worse security challenges in Taraba State. This paper examined identity crisis with the view to determining the extent this has exacerbated the crisis in Wukari. The paper observed that understanding the role of identity in Wukari's multifarious conflicts is a crucial step in establishing the linkages of several other dynamics that underlie its causes and persistency. It argued that identity dichotomy among the Jukuns has deepened grievances leading to seven disastrous conflicts in the last two years. The complex web of dynamics that often provokes these conflicts has also stalled peace-building processes. The paper adopted qualitative descriptive method of analysis while relying on the political economy approach as its theoretical guide. This approach appeared adequate for the study because it emphasized identification of themes in texts and documents that focused on the major propositions under test. It recommended all inclusive peace initiative that will involve government and stakeholders from various segments of the community towards ensuring sustainable peace in Wukari.
\end{abstract}

Keywords: Identity, Peace-Building, Wukari.

\section{Introduction}

In the last few decades, the global system has continued to witness increase outbreak of ethno-religious and intra-state conflicts. Specifically, in the last two decades such conflicts have remained the most destabilizing element in the contemporary societies. Nigeria's return to democratic governance in 1999 produced a climate that precipitated the resurgence of identity crisis in the political landscape. This seems to have intensified identity conflicts in Nigeria especially in areas where inequality and primordial ties have gained significant status. In each of these, huge humanitarian tragedy and socio-economic disaster accompanying the tide appears to have deleterious effect on entire development process. In fact, it seems to have blotted stability, instigated socio-economic and political disarticulation in Wukari. This seems to pose direct consequences on the development of Wukari communities and the nation at large.

Thus, the genesis of Wukari crisis could be traced to the 1959 prior to the independence. For instance, Nnoli (1995) observed that the emergence of overt conflicts between the Jukun and Tiv ethnic groups, particularly from 1959, and their continuation since then, have turned this feud into "the deadliest inter-ethnic clashes"(cited in Aluaigba, 2008). Several other scholars (Anifowose, 1982; Nnoli, 1995; Egwu, 1998; Jibo, 2001; Egwu, 2004) have described ethnic and communal confrontations in Nigeria mainly between the Tiv and the Jukun as one of the most devastating conflicts in Nigeria.

Evidently, Wukari Crisis has evolved several stages in terms of causes, magnitude; people involved in the crisis, velocity of occurrence, preventive measures and general impacts. For instance, between 2013 and 2014 Wukari has suffered seven devastating fratricidal conflicts in which lives and property worth millions of Naira were ruthlessly destroyed (Nwanegbo, Odigbo \& Ngara 2014). For instance, the first crisis in 2013 the available reports put death toll at hundred (100) (see Ayodele, 2013), while about 300 houses were burnt (Mkom, 2013). In spite of the fact that these estimations may not be the true reflection of the condition in Wukari especially in terms of number of victims and destruction, thus it appears that the continuation of the crisis is threatening to wipe out some sections of the community.

It is against this backdrop that this study seeks to examine the place of identity in the compounded and continually deepening Wukari crisis. This is to determine the extent it has impacted on the present crisis in Wukari. It also investigates whether the deepening identity challenge played any significant role in scuttling peace-building efforts that caused the Wukari community to slide back to violence seven times in eighteen months. 


\section{Conceptual Clarification}

The concept of identity can be seen as a global phenomenon. As a concept it is linked to state identity, national identity, transnational identity, ethnic identity, tribal identity, social identity, individual or personal identity (Plessis, 2001). As can be seen, several scholarly attempts at defining the concept seem to have produced glut definitions yet the concept of identity is still fraught with definitional vagueness. In this regard, Lapid (1996) posited that what has emerged over the past years are parallel redefinitions of identity that merely add multiplicity and social construction to existing definitions (cited in Plessis, 2001).

Indeed, (Osaghae \& Suberu, 2005; Plessis, 2001; Faleti, 2005; Arena \& Arrigo, 2006) have identified various classifications and separately contended that identity has remained a major element that generates and reinforces conflicts, competition for state control and ownership of resources. Osaghae \& Suberu, (2005) broadly defined identity as any group attribute that provides recognition or definition, reference, affinity, coherence and meaning for individual members of the group, acting individually or collectively. They further explained identity from the perspective of Geertz (1963) famous distinction between primordial ties which are basically ascriptive and based on the "givens" of life (tribe, kinship, and ethnicity among others), and civil ties, which hinge on industrial society-type aggregations like class, political party affiliation, interest group membership, and so on (Osaghae \& Suberu, 2005).

However, Plessis (2001) contended that because identity is more about substance than form, the notion that it is essential, fundamental, unitary and unchanging should be rejected in favour of the idea that changing identities are constructed and reconstructed through socio-historical action. For him, since identity, and more specifically ethnic identity in the African context, is primarily linked to the state and to the conflict-generating effect of negative identity, note must be taken of positive identity as a basis for cooperation and transformation (Plessis, 2001). Thus, positive identity plays a crucial role for sustainable transformation. But such identity is not developed in isolation. The historical antecedent of a given society and secondly the character of the state tend to determine the pattern of identity that would likely emerge in any society. For instance, the decision of groups or individuals to identify themselves ethnically or religiously is the function of their interest that is dependent on the nature and scale of contestation. It is within this context that identity in Africa seems to be conceived from negative standpoint.

It is important to note that identity crisis in which ever form may spell doom for any society. The psychological consciousness and cultural ties collectively or individually express by people or persons sometimes may be a justification for untoward responses in addressing issues concerning ones identity. Mostly, these responses tend to be conflictual and damaging. Just as Faleti (2005) argued, conflicts that are caused by a crisis of identity are usually the most dangerous and most violent because identity is an unshakable sense of self-worth, which makes life meaningful and includes the feeling that one is physically, socially, psychologically, and spiritually safe. Evidently, in Nigeria identity clashes have assumed worrisome dimension since independence. In fact, Osaghae \& Suberu (2005) further argued that Nigeria presents:

A complex of individual as well as crisscrossing and recursive identities of which the ethnic, religious, regional and sub-ethnic (communal) are the most salient and the main bases for violent conflicts in the country. This is both from the point of view of the identities most commonly assumed by citizens especially for political purposes and the identities often implicated in day-to-day contestations over citizenship as well as competitions and conflicts over resources and privileges (Osaghae \& Suberu, 2005:8)

Following from the above, we emphasized that primordial identities tend to have deepened the crisis in Wukari especially among the Jukuns. This is basically, because of the contestations over citizenship, 'indigenes', 'non-indigenes', 'migrants', and 'settlership' dichotomy (Nwanegbo, Odigbo \& Ngara 2014). These groupings or rather classifications have sustained discriminatory practices and exlusionism in the management of communally owned resources. Consequently, the tendency to resort to violence owning to accumulated grievances seems fashionable than dialogue.

Indeed, restoring peace in Wukari demands a sustainable peace-building strategy. This is essential especially when put into consideration the fact that experience on ending wars, conflicts and violent conflicts have shown that conflict does not always end until a completely fresh environment are built from the wrecks of the devastated society, making the societies acceptable and people feeling accepted in it. That is peace building. It is a major practical step and planned efforts to transcend immediate political difficulties through technical collaboration designed to find solutions to common socio-economic, physical and environmental problems affecting the city (UNDP cited in Nwanegbo \& Odigbo, 2013).

In his view, Galtung (1975) sees peace building as one of the measures of intervening in conflict in order to overcome the contradictions at the root of the conflict formation. Peace building involves establishing normalized relations 
between ordinary citizens on both sides of a conflict. It includes all efforts to restore "normalcy", cooperative contacts between opponents. In this regard, David (1999) analogy is guided by three basic features of the concept of peace building. These include:

1. The rehabilitation, reconstruction, and reconciliation of societies that have suffered the ravages;

2. The creation of security - related, political and/or socioeconomic mechanisms needed to build trust between the parties and prevent the resumption of violence;

3. An external intervention (national multilateral or UN) to create conditions to peace.

Thus, peace-building provides various transformation techniques aimed at moving parties away from confrontation and violence, and towards political and socio-economic participation, peaceful relationships, and social harmony. This longer-term perspective is crucial for future prevention of violence and the promotion of a more peaceful future. Thinking about the future involves articulating desirable structural, systemic, and relationship goals. These in the opinion of Nwanegbo \& Odigbo (2013) might include sustainable economic development, self sufficiency, equitable social structures that meet human needs, and building positive relationships. Hence, it could be stated that Peace-building initiatives try to fix the core problems that underlie the conflict and change the patterns of interaction of the parties involved. They also aim to move a given population from a condition of extreme vulnerability and dependency to one of self-sufficiency and wellbeing.

\section{Theoretical Compass}

This study adopted political economy approach in the analysis of the contradictions that have nurtured and sustained identity crisis in Wukari. Our choice of the theory is predicated on the fact that the approach looks at the society holistically for explaining challenges and dynamics that underlie societal problems. The approach scientifically studies the society in its totality and takes into consideration the interconnection of social relations, class conflict and the organic relationship between the sub-structure (economy) and the super structure (politics).

Thus, political economy is concerned with the social laws of production and distribution (Lange, 1974). For Adler, (2009) political economy refers to the combined and interacting effects of economic and political structures or processes, and by extension, to the scholarly study of this domain. In fact, it tended to focus on the production, reproduction and distributive responses of invariant structures. In his view, Gilpin (1987) argued that the distribution of power and the nature of the political system are major determinants of the framework within which wealth is produced and distributed.

It is also imperative to assert that while we appreciate and acknowledge the explanatory vigor of political economy approach in explaining the dynamic character of societies and conflicts, we are also not unaware of its reductionist view point that not every conflict or problem can be attributed to the struggle for the scarce resources. However, considering the severity of violence in Wukari, political economy approach becomes not only relevant, but the bedrock for understanding the drivers of the conflict in the last few years. Indeed, part of the current crises, as with other conflicts in Wukari, is inextricably linked with competition for resources.

As can be seen, there are several inter-group contest for political, economic and socio-cultural values in Wukari. Essentially, groupings and subsequent confrontations arising from it reflect genealogy identities and interest of different group identities in Wukari community. Also important to note is the fact that a large number of economic activities and businesses in the community seem to be owned by "non-indigenes" especially by the Tivs, Hausas and Igbos. It is actually the control of these economic activities that nurtures internal bickering among the indigenous Jukuns and Jukuns with mix genealogy. The dominance and perceived alliances of the "Hausa-Jukuns" or "Jukun with mixed genealogical traces" over the control of parks, markets and other internally means of generating funds appears to have placed the Jukuns as visitors. Indeed, the growing consciousness to avert future extinction from the control of means of production and distribution ignited internal squabbles among the Jukuns. For instance, this led to the emergence of "old and new market, the old and main parks" etc.

Thus, the destruction of old parks and old markets is an indication that the conflicts seem to have primarily economic connotation. Several reprisal attacks have further deepened the conflicts and since then develop several other sentiments that hinder peace process. As the conflicts persist, many businesses have been relocated from Wukari and strangers in the community seem to have remained under perpetual anxiety over the hostility in Wukari.

\section{The Dilemma of Identity Crisis in Wukari}

Identity has come to mean several things to many people. Though, it could be argued that identity serves several 
purposes, the extent these aims can achieve maximum happiness for collective good still remains source of contest in many societies. More importantly, is the fact that the misuse and misapplication of identity especially to gain advantage over others or gain access to an unmerited status has remained one of the challenges confronting the concept of identity. Thus, Kuna as in Alubo (2009) distinguishes identity to be either objective or subjective. According to him,

An identity is a distinguishing label that objectively exists, is subjectively felt, and enables its bearers to experience individually and collectively a sense of solidarity. Identities are socially constructed, dynamic and multifaceted. Subjectively, identification with a category is simultaneously a definition of self, so that groups come to identify themselves as ethnic, religious, occupational, national and other terms. Objectively, individuals do not identify in general, but do so in relation to others' definitions of themselves and the boundaries implied in such definitions (Kuna cited in Alubo, 2009: 2).

Identity conflict is often a competition for ownership of the state and control of its resources (Adeyeye 2013). For him, conflicts of identity are likely to escalate when groups and/or group members consider that the recognition accorded a competitor identity can threaten their own. This consciousness is likely to motivate acts capable of checkmating the increasing awareness or acceptance of a particular identity. Identities crafted for political and economic purposes seem to generate more conflicts because social relations and survival are largely dependent on the material condition of man. For instance, Nwanegbo e tal (2014) rightly argued that discrimination on the basis of indigeneship or citizenship is quiet problematic because it is directly tied to individual or group access to societal resources including political opportunities. For them, this has served to further sharpen the "we" and the "you" divide. Earlier, Albert as in Adeyeye (2013) argued that:

the 'self concept- I and/or WE against OTHERS' motivates identity consciousness which further play out in the symbolic nature of social structure, stratification and the enhancement of individual status as profound influences on the emergence of one's sense of self and, ultimately one's group identity (Adeyeye 2013:119).

Ultimately, the orgy of violent confrontations among the Jukuns has further intensified the polarization of Wukari communities. Identity has swiftly increased the tempo of division among people in Wukari. It also has created a bifurcated settlement pattern, increases suspicion among the Jukuns. Evidently, Wukari epitomizes a tale of "two" communities in "one". The one accepted and inhabited by the "sons of the soil", abiding settlers and non-indigenes and the other repulsively destroyed and isolated as a result of the perennial wars.

Understandably, part of these challenges can be explained from the fact that Jukuns seem to have poor understanding of the role of their language. As a result, many prefer teaching and educating the children in Hausa language in lieu of Jukun language. This has not only made Hausa language popular in Jukun land but has dominated and even become more acceptable means of interaction in most public places. Thus, such unconscious behavior tends to have eroded ethnic uniqueness and the pride derivable from being a member of an ethnic group. Arguably, language is prestigious and defines a person both in character and identity.

Unfortunately, the Jukuns have existed for many decades as ethnic group in Nigeria yet has not developed a means of codifying the Jukun language. The implication is that as the language match on its way to extinction, the people will definitely pledge their loyalty to another ethnic group. Surprisingly, Wukari Local Government Council is implicated in this identity conundrum. For instance, a closer look at identification letters given by the Wukari Local Government, one reads "Hausa-Jukun" and the other reads "Jukun". Presently, some Jukuns accept being addressed as Hausas than being Jukun. And indeed, many especially those addressed as Hausa-Jukuns do not speak nor understand Jukun language.

Consequently, identity crisis has further polarized religion in Wukari. A Jukun Muslim prefers and feels safe with a Hausa Muslim than Jukun relations. In this condition, such a person identifies self as Hausa. On the other hand, Jukun traditionalist stick to their Christian relatives and they indeed see themselves as the real Jukuns. Following from the above, it could therefore be stated that erroneous misconception of the Jukuns as being Hausas, accommodation and acceptance of other language to the detriment of Jukun language and non-codification of Jukun language has developed complex web of challenges responsible for persistent conflicts in Wukari.

\section{Wukari Crisis: Evolving from Ethnic Confrontations to a Fratricidal Ruin}

For the past few decades, the crisis in Wukari has been more of inter-ethnic struggle involving the Jukuns and Tiv, Jukuns and Kuteps, Jukuns and Hausas. Though, these conflicts have been devastating, however, it was the Jukun-Tiv ethnic violence that appears to be more disastrous. Thus, the emergence of overt conflicts between the two ethnic groups, particularly from 1959, and their continuation since then, have turned this feud in what Nnoli (1995) has described 
as "the deadliest inter-ethnic clashes" (cited in Aluaigba, 2008). Surprisingly, there seems to be no end to the conflict as each decade since the 1950s keeps resonating with new waves of the Tiv-Jukun brawl (Aluaigba, 2008).

Arguably, the height of these clashes was the conflict in 2001. In this incidence, the level of bloodshed and property destruction in both the Jukuns and Tiv communities were unimaginable. Thus, the former Senate President while visiting Akwana, one of the 25 villages which was reduced to rubble termed the destruction as "despicable and horrendous" (Adamu, 2002). What actually exacerbated 2001 conflict was the killing of soldiers who were on lawful duty. According to Adamu (2002), the destruction of Zaki-Biam came in the wake of the cold-blooded slaughter of 19 soldiers on a peace mission to the trouble Taraba/Benue border areas by Tiv militia. As can be seen, the Tiv-Jukun conflict is among the numerous ethnic conflicts that have blotted stability and instigated economic and social dislocation in Nigeria lately (Aluaigba, 2008; Avev, 2002). In fact, it has become one of the protracted inter-ethnic clashes (Egwu, 1998) that began prior to independence in 1960.

However, the most recent conflicts in Wukari which started between March and May 2013 introduced citizenship, indigeneship/settlership dimension that underlies identity "apocalypse" in Wukari. Though, there has been long years of accumulated grievances yet the Jukuns have cope with the anger among themselves over the years. The 2013 crisis seems to be the first time the Jukuns inflicted a massive destruction in Wukari town which is known as the seat of power for all the Jukuns. The conflicts have succeeded in dividing pattern of settlement in the city between the Jukun Christians/Traditionalists and the Jukun-Muslims/Hausa-Fulanis and divided families along religious lines. Indeed, the level of distrusts among them can be seen even in the way they cluster along defined/identified groups in the places they live in Wukari and its environment. As a matter of fact, on entry to Wukari, a visitor can easily identify where the Jukun and Christians live and where the Hausas and Jukun Muslims stay. This made attacks and counter attacks since 2013 more devastating since "enemies" territory is clearly defined.

Noticeably, the conflicts have created ghost areas in some areas of Wukari town. For instance, the popular old market areas, Kampo areas, the ambassador round-about and Byama road where over a thousand houses were destroyed, have been abandoned and isolated by people. Indeed, the deep rooted nature and complexity of this fratricidal conflict in Wukari seem to have sustained it resistance to peaceful resolution. This is mainly because identity in Wukari which is the core driver of the crisis is yet to be resolved.

\section{Challenges of Peace-building in Wukari}

Generally, peace-building involves planned and sustained efforts towards restoring normalcy and peace in a conflict torn environment. It helps to reinvigorate ravaged societies to an acceptable and habitable state. To raise such conflict devastated areas to acceptability means that strategies for its realization will not only be sustainable but also inclusive. In this regard, both the "victims and victors", non-government organizations, stakeholders and government at all level play a crucial role. All in an effort to achieve durable peace capable of preventing such communities or societies from sliding back to violence. Thus, the UN systems have provided us with some basic steps towards peace building. Some of them include:

- Assisting an end to military or violent exchanges through the decommissioning of arms, the demobilization of combatants, and rehabilitation and reintegration programs

- Providing humanitarian relief to victims

- Protecting human rights

- Ensuring security and related services

- Generating an environment of trust in order for social relations to function properly

- Establishing non-violent modes of resolving present and future conflicts

- Fostering reconciliation among the various parties to a conflict

- Providing psycho-social or trauma healing services to victims of severe atrocities

- Repatriating refugees and resettling internally displaced persons

- Aiding in economic reconstruction

- Building and maintaining the operation of institutions to provide such services, and

- Co-coordinating the roles of numerous internal and external parties involved in such interrelated efforts (Adopted from the A Glossary of Terms and Concepts in Peace and Conflict Studies, by Miller \& King 2004).

Following from the above prescriptions, it could be noted that most of the indices that may enhance peace in Wukari is still lacking. For instance, poor commitment by the federal government towards building and maintaining the operation of institutions to provide such services needed for restarting these communities again tends to have limited 
chances of resolving outstanding problems. Arguably, the state government seems to also been implicated in complicating the violence. This could also be seen from the perspective of political drama since Governor Danbaba Suntai plane crash that seems to have incapacitated the Governor, and the growing agitation by some sections and groups to confirm the incumbent acting Governor Garba Umar as the Governor of the State.

However, there are few efforts by stakeholders in Wukari to find lasting solution to the crisis. This includes the Rtd. Lt. Col. Agbu Kefas peace initiative that began after the second crisis and few other local efforts. The twenty man committee plus some stakeholders from State Security Service, Wukari Local Government representative, the Army, the Police etc were duly part of the group. This committee engaged a wide range of consultation from the civil society, traditional institution in Wukari, market leaders and representatives of several interest groups. The committee came up with the following suggestions;

a. There is need for justice in all ramifications, people should not take laws into their hands, whoever has done something wrong no matter who he is, no matter who his/her parents are, he/she should be punished according to the law of the land.

b. Government should find way of reducing unemployment in the society

c. There is need for more police out-posts in wukari, at least one in 'Wapan Nghaku', one in 'Takum Junction', one in 'Kinkinso' and one around former 'Marmara Guest Inn'.

d. Fight against drugs abuse should be intensified by the NDLEA and other security operatives.

e. Pastors and Imams should be encouraged to preach peace; any utterances that will create problems should be discouraged. Any Pastor/Imam caught saying anything that will create problem should be dealt with by the government

f. Everybody should be allowed to promote his/her culture and peace

g. 'Achaba' (commercial cyclists) users should be registered by relevant body, this will help in knowing who and who are members of the group (Wukari Development Forum's report, 2013).

Thus, in spite of the impacts of these recommendations, it has failed to ensure adequate peace hence Wukari relapsed to conflict five times after this peace initiative. We emphasized that the peace initiative as well as several other peace processes failed as a result of the following:

a. Lack of commitment by governments at all level towards building peace in Wukari. This could be seen from the fact that there is no effort at reconstructing the communities that were horrendously devastated by the war. Secondly and perhaps more importantly is the inability of the government to provide social services in areas affected and non provision of relief materials to many internally displaced people. Till date, Wukari East primary school still houses thousands of Jukuns that were recently attacked by armed men.

b. Disdainfulness of parties involved in the conflict.

c. These arrangements have failed to map out realistic strategies for implementing these recommendations.

d. Lastly, is the fact that the recommendations do not unravel the remote causes of the violence. In fact, it dwells much on the immediate and other peripheral causes.

Following from the above, we note that with the magnitude of devastation and destruction in Wukari couple with the complexity of the crisis, it appears that finding remedies to the present condition is beyond individuals and even groups. There is need for government to drive peace process in the community. While engaging stakeholders and civil society groups, the government also needs to rebuilding infrastructures devastated during the war. There is need to re-orientate the people, inculcate new philosophy that would sustain peace in Wukari.

\section{Conclusion}

From the analysis we reaffirmed the fact that the Jukuns have endured frosty relationship with their neighbours especially the Tiv. This form of relation has conditioned the relations of the Jukuns with migrants who have settled in Wukari over the years. However, it is the opinion of the paper that the remote cause of the recent seven successive conflicts in Wukari between 2013 and 2014 was as a result of identity crisis that underlies citizenship, indigeneship contestation. This is because identity plays a central role in ones capacity or opportunity to access and distribute scares communal resources. Indeed, we noted that there has been no sufficient effort by government to end this violence. The presence of soldiers is not enough. It has not even prevented the recurrence of the conflicts.

The implication is that government needs to look beyond deployment of troops. Solving this problem is largely dependent on the capacity of the Nigerian state to evolve adequate strategy to deal with identity challenge that seems to have created what is popular described as the "national question" which borders on citizenship in Nigeria. In fact, 
addressing Wukari crisis is a challenge that demands a collaborative effort. It is based on this that we recommend all inclusive peace initiative that will involve government at all level, institutions, interest groups, religious and traditional institutions, town union leaders and other stakeholders from various segments of the community towards ensuring sustainable peace in Wukari.

\section{References}

Adamu, D. (2002). Issues in Tiv-Jukun Conflict, Land, History and Politics. Jos: Target Publicity.

Adeyeye, A. (2013). Identity Conflict, Terror and the Nigerian State: Between Fragility and Failure. Journal of Sustainable Development in Africa ,15 (4): 116-129

Adler, P.S. (2009). "Marxist Philosophy and Organization Studies: Marxist Contributions to the Understanding of some Important Organizational Forms" in H. Tsoukas, \& R. Chia, (eds.), Research in the Sociology of Organizations: Philosophy and Organization Theory. JAI Publishers.

Aluaigba M. T. (2008). The Tiv-Jukun Ethnic Conflict and the Citizenship Question in Nigeria. Aminu kano Center for Democratic Research and Training. Kano: Bayero University.

Alubo, O. (2009). Citizenship and Identity Politics in Nigeria. lagos: Cleen Foundation.

Anifowose, R. (1982). Violence and Politics in Nigeria: The Tiv and Yoruba Experiences, Lagos: Nok Publishers.

Arena, M. \& Arigo, B. (2006). The Terrorist Identity: Exploring the Terror Threat. New York: New York University Press.

Avav, T. (2002). Refugees in our own Country: The Tiv-Jukun Crisis, 1990-1993, Abuja: Supreme Black Communications.

Ayodele, W. (2013). "Wukari Boils Again" Thisday May 4, 2013. Pp. 2.

David, C.P. (1999). Does peace building build peace?" In: Security Dialogue; Volume 30, No. 1, March 1999. London. Sage Publication.

Egwu, S.G. (1998). "Agrarian Question and Rural Ethnic Conflicts in Nigeria". In O. Nnoli (ed.) Ethnic Conflicts in Africa, Dakar: CODESRIA, pp. $53-77$.

Egwu, S.G. (2004). Contested Identities and the Crisis of Citizenship in Nigeria. Nigerian Journal of Policy and Strategy, 14 (1): 40 - 64.

Faleti, S.A. (2005). Termination of protracted social conflicts in Africa: victory or consociation? In Albert, I.O. (ed.) perspectives on peace and conflict in Africa. Essays in Honour of General (Dr.) Abdulsalami A. Abubakar: Ibadan: John Archers (Publication) Limited.

Galtung, J. (1975). "Three Approaches to Peace: Peacekeeping, Peacemaking and Peacebuilding" in J. Galtung (ed.), Peace, War and Defence: Essays in Peace Research, Copenhagen: Christian Ejlers.

Gilpin, R. (1987). The Political Economy of International Relations. New Jersey: Princeton University Press

Jibo, M. (2001). The 2001 Tiv Massacre: Accountability and Impunity in Nigeria's Fourth Republic. University of Jos Journal of Political Science 2 (3): 1-13.

Lange, O. (1974). Political Economy. Warszawa: PWN-Polish Scientific Publishers.

Miller, C. \& King, M. (2004). A Glossary of Terms and Concepts in Peace and Conflict Studies. University for Peace Press.

Mkom, J. (2013). "5 Killed, 300 Hundred Houses Burnt in Taraba Crisis" The Sun, February 24, 2013. Pp. 1 and 6.

Nnoli, O. (1995). Ethnicity and Development in Nigeria, Aldershot: Avebury.

Nwanegbo, C. J. \& Odigbo, J. (2013). "Post Independence Peace Building in South Sudan: Looking Beyond Ephemeral Peace", International Journal of Social Science Tomorrow, 2 (1): 1-10

Nwanegbo, C. J., Odigbo, J. \& Ngara, O. (2014). Citizenship, Indigeneship and Settlership Crisis in Nigeria: Understanding the Dynamics of Wukari Crisis. Journal Research in Peace, Gender and Development, 4 (1): 8-14.

Osaghae, E.E. \& Suberu, R. T (2005). A History of Identity, Violence and Stability in Nigeria. Centre for Research. on Inequality, Human Security and Ethnicity: Oxford University.

Plessis, A. (2001). Exploring the Concept of Identity in World Politics. Being a Seminar Paper Presented at the University of Pretoria, July $25^{\text {th }}-26^{\text {th }}$.

Wukari Development Forum (2013). Report of the finding on Wukari Crises and recommendation for achieving peace in Wukari. 
